\title{
Influence of organic or inorganic forms of salts rich in phosphorus, copper and zinc on reproduction, productivity and blood constituents in sheep
}

\author{
Abd El-Hamid, I, S.; Younis, F. E.; Farrag, B.; El-Rayes, M. A-H and Shedeed, H, A. \\ Animal and Poultry Production Division, Desert Research Center, Ministry of Agriculture and Land Reclamation, Egypt.
}

Corresponding authors: Ibrahim Samir Abd El-Hamid, PhD

Animal and Poultry Production Division, Desert Research Center, Ministry of Agriculture and Land Reclamation, Egypt.

Email: Ebrahimsamir@yahoo.com

Received date: 12 April 2019, Accepted date: 25 June 2019, Online date: 29 June 2019

Copyright: (C) 2019 Abd El-Hamid, I, S. et al., This is an open-access article distributed under the terms of the Creative Commons Attribution License, which permits unrestricted use, distribution, and reproduction in any medium, provided the original author and source are credited.

\begin{abstract}
Thirty- nine mature Aboudeleik ewes were fed the basal diet and divided into three groups. The first one was served as control (n=12), the second group received the basal diet plus salts in organic form $(2.7 \mathrm{~g} / \mathrm{h} / \mathrm{d} \mathrm{DM}, \mathrm{n}=14)$ while the third one received $(2.7 \mathrm{~g} / \mathrm{h} / \mathrm{d} \mathrm{DM}$, $n=13$ ) salts in inorganic form. The supplementation period began one month before mating and continued for waning period. Estrus was synchronized using duple injections of $\mathbf{P G F}_{2 \alpha}$ prior to the introduction of rams. Serum progesterone profile, blood biochemical constituents and elements concentration were determined during different pregnancy stages. Reproductive performance, productive traits of lambs including birth, weaning weights and average daily gain were also determined. The obtained results declared that the concentration of serum progesterone $(\mathbf{P} 4)$ was higher $(\mathbf{P}<0.01)$ in organic or inorganic-S groups compared with control. Feeding trace element in organic or inorganic salts resulted in a higher $(\mathrm{P}<0.05)$ conception rate, while lambing and prolificacy rates increased $(\mathbf{P}<\mathbf{0 . 0 5})$ in inorganic-S compared with organic-S or control groups. Sex ratio of lambs born from treated ewes was not affected. Furthermore, treatment had no effects on total proteins (TP), albumin (Albu), globulin (Glo), urea concentrations, aspartate aminotransferase (AST) and alanine aminotransferase (ALT). However, lipid metabolites including total lipids (T.L), cholesterol (Cho) and triglycerides (TG) concentrations increased $(\mathbf{P}<0.05)$ in treatment groups as compared to control. While serum creatinine $(\mathrm{Crea})$ concentration was higher $(\mathbf{P}<\mathbf{0 . 0 5})$ in control group than organic or inorganic-S. Serum calcium $(\mathrm{Ca})$, selenium $(\mathrm{Se})$ and iron $(\mathrm{Fe})$ concentrations were not different among treatment groups. While, serum phosphorus (P) and copper (Cu) concentrations increased $(\mathrm{P}<0.01)$ in treated groups compared with control. Birth weight for lambs born from ewes supplemented with organic salts was higher $(P<0.05)$ than those born from ewes supplemented with inorganic-S or control. Weaning weight and average daily gain for lambs of treated ewes increased $(P<0.05)$ as compared to control ones.

In conclusion, the efficiency of different forms organic and inorganic of salts rich in phosphors, copper and zinc was similar and greatly affected progesterone concentration, lipid metabolism, phosphorus and copper concentrations in serum blood during different pregnancy stages and has a positive effect on the weight of lambs.
\end{abstract}

Keywords: Aboudeleik, sheep, minerals, pregnancy, trace-elements, serum biochemistry.

\section{INTRODUCTION}

Halayeb-Shalateen and Abu Ramad Triangle is located at the border between Egypt and Sudan, on the African coast of the Red Sea and has an area of 20,580 square kilometers. Livestock in Halaieb-Shalateen-Abu Ramad Triangle is limited in sheep and goats. Aboudeleik sheep is considered one of the important breeds to produce milk and meat in the Triangle, because of their persistence to the harsh conditions (Khalil et al., 1990). The average body weight is $45 \mathrm{~kg}$ and the body is shallow with long legs and covered with short hair. The head, neck are long in both sexes long often with dewlap. The tail is cylindrical and longreaching below the hocks; ears are absent or small with backward downward.

The color is dark or brown with cream; wattles are rare (DRC, 1996). The pasture in Halaieb-Shalateen-Abu Ramad triangle region contains three main plants which are poor in nutritional value, namely Panicum turgidum, Lyicum shawii and Acacia tortilis (El-Shaer et al., 1997). There is no available information about reproductive performance, production characteristics and estimates of the genetic parameter (Badawy et al., 2018). Metabolism of blood biochemical and trace minerals in sheep are still yet to be clarified under arid conditions and environmental stress during different physiological status (Samir, 1990). Trace elements supplementation has become indispensability in the feeding of ruminants (Kim and Mahan, 2002; 
Citation: Abd El-Hamid, I, S. et al., Influence of organic or inorganic forms of salts rich in phosphors, copper and zinc on reproduction, productivity and blood constituents in sheep. Australian Journal of Basic and Applied Sciences, 13(6): 14-22. DOI: 10.22587/ajbas.2019.13.6.2

Boldizarova et al., 2005; Hylland et al., 2009) for the complete saturation of animals from trace elements, especially in arid and impoverished pasture areas. Trace elements play an important role in the regulation of the physiological function of ovarian activity, gestation period and the mechanism of the digestive, nervous system (Krajnic a'kova' et al., 2003). The decrement of trace elements diets provokes the weak of immune capacity in ewes and newborn lambs (Turner and Finch, 1990; Rodinova et al., 2008). Zinc ( $\mathrm{Zn})$ and copper $(\mathrm{Cu})$ play important roles in many biological functions including protein synthesis, cellular division and nucleic acid metabolism (Davis and Mertz, 1987; Zhang et al., 2012). Studies on several animals such as mice, pigs and ewes concluded that severe zinc deficiency led to highly embryonic loss due to spontaneous abortions (King, 2000) and multiple congenital anomalies such as malformations of the heart, lungs, and skeletal system (McArdle et al., 2006; Jou et al., 2010). Copper $(\mathrm{Cu})$ and cobalt $(\mathrm{Co})$ are essential elements required for ruminant diets to enhance blood function especially lipid metabolism in sheep (Cheng et al., 2008; Abou El-Ezz and Younis, 2010), goats (Zhang et al., 2012) and cows (Wittenberg and Boila, 1988; Ward and Spears, 1997).

Also addition of trace elements such as copper $(\mathrm{Cu})$ and cobalt $(\mathrm{Co})$ to diets of animals led to improvement of reproductive performance of dams (Aliarabiet al.,2019; Quirk and Norton, 1987), and growth performance, quality meat, fiber characteristics in newly born (Badawy et al., 2018; Huang et al., 2014; Kadim et al., 2003). Sodium ( $\left.\mathrm{Na}^{+}\right)$is the major cation of extracellular fluid, while potassium $\left(\mathrm{K}^{+}\right)$is the major cation in the intracellular fluid. The major functions of $\left(\mathrm{Na}^{+}\right.$, $\left.\mathrm{K}^{+}\right)$ions are to regulate osmotic pressure, the acid-base balance, and maintenance of membrane potential, the transmission of nerve impulses and development of membrane potentials (Hays and Swenson, 1977).

\section{MATERIALS AND METHODS}

\section{Animals and management}

Thirty- nine Aboudeleik ewes, average body weight of $37.5 \pm 3.75 \mathrm{~kg}, 3-5$ years old, kept in a Ras Hederba Valley region, Shalateen Experimental Research Station, Shalateen-Halaieb -Abu Ramad Tringle Region, Red Sea Governorate, located $1300 \mathrm{Km}$ of Cairo (Latitude 22, 00,720 N and longitude 36, 48.955 E). Animals were housed in semi-open pens throughout the experimental period from Sep 2016 to March 2017. Animals grazed on natural pasture about 6 hours daily and received a palliated concentrate mixture $(500 \mathrm{gm} / \mathrm{head} /$ day) as basal diets (Table 1). Freshwater was presented twice daily before and after going to grazing. Animals were free of any diseases or reproductive disorders. All experimental procedures were conducted in conformity with the EU Directive for the protection of experimental animals (2010/63/EU).

\section{Experimental design}

Thirty-nine Aboudeleik ewes were randomly divided into three groups. The first group: control $(\mathrm{n}=12)$ received the basal diet, the second group (Organic-S; $n=14)$ received the basal diet that plus $(2.7 \mathrm{gm} / \mathrm{head} / \mathrm{day}$ DM) of salts additive mixtures which contain $(\mathrm{Cu}, \mathrm{Zn}, \mathrm{Mg}$ and $\mathrm{Co})$ in organic form. The third group (Inorganic-S; $\mathrm{n}=13)$ received the basal diet plus $(2.7 \mathrm{gm} / \mathrm{head} / \mathrm{day}$ $\mathrm{DM})$ of salts mixtures $(\mathrm{Cu}, \mathrm{Zn}, \mathrm{Mg}$ and $\mathrm{Co}$ ) in inorganic form (Active Vet, USA). The experiment started one month before mating and continued for the waning period. The chemical composition of the basal or treated diets is presented in (Table 1).

Table 1. Ingredients and chemical composition of concentrate mixture and trace elements of treated diets for Aboudeleik sheep.

\begin{tabular}{|c|c|c|c|}
\hline \multicolumn{4}{|c|}{ Treatment diets } \\
\hline Ingredient & $\begin{array}{c}\text { Composition } \\
(\%)\end{array}$ & Concentrate mixture & $\mathrm{g} / \mathrm{kg}$ \\
\hline Yellow corn & 25 & Organic matter & 940 \\
\hline Cottonseed meal & 16.7 & Ash & 60 \\
\hline Wheat bran & 30 & Crude protein & 148 \\
\hline Sunflower meal & 25 & Ether extract & 55 \\
\hline $\mathrm{NaCl}$ & 1 & Neutral detergent fiber & 534 \\
\hline Limestone and common salt & 2 & Acid detergent fiber & 369 \\
\hline Trace minerals* & 0.3 & Hemicellulose & 165 \\
\hline Trace elements (g/kg DM) & Control & Organic form & Inorganic form \\
\hline $\mathrm{P}$ & 0.71 & 1.25 & 1.67 \\
\hline $\mathrm{Zn}$ & 0.63 & 1.35 & 2.00 \\
\hline $\mathrm{Fe}$ & 0.42 & 1.25 & 1.00 \\
\hline $\mathrm{Cu}$ & 0.62 & 3.75 & 3.33 \\
\hline $\mathrm{Se}$ & 0.41 & 0.63 & 0.66 \\
\hline Co & 0.21 & 0.13 & 0.16 \\
\hline Iodine & - & 0.15 & 0.5 \\
\hline $\mathrm{Caco}_{3} *$ & - & - & 990.7 \\
\hline Lysine* & - & 991.5 & - \\
\hline
\end{tabular}

$\mathrm{Caco}_{3} *(\mathrm{gm})=$ Carrier Material. Lysine* $(\mathrm{gm})=$ Carrier Material. 
Citation: Abd El-Hamid, I, S. et al., Influence of organic or inorganic forms of salts rich in phosphors, copper and zinc on reproduction, productivity and blood constituents in sheep. Australian Journal of Basic and Applied Sciences, 13(6): 14-22. DOI: 10.22587/ajbas.2019.13.6.2

\section{Synchronization of estrus}

All animals were estrus synchronized using double injunction $(1 \mathrm{ml}, \mathrm{i} . \mathrm{m}$.) of prostaglandin PGF $2 \alpha($ Estrumate, $263 \mu \mathrm{g}$ Cloprostenol/ml, Schering-Plough Animal Health, Germany) 9days apart.

\section{Estrus exhibition and mating}

Exhibiting estrus was detected using tracer ram that was fitted with dye markers throughout 72 hours. Ewes that exhibited estrus were naturally mated using mature fertile rams.

\section{Blood collection}

Jugular blood samples were collected from all animals in serum vacutainer tubes $5 \mathrm{ml}$ to determination progesterone concentrations $\left(\mathrm{P}_{4}\right)$ after $72 \mathrm{hr}$. of the $2^{\text {nd }}$ of $\mathrm{PGF}_{2 \alpha}$ injection: day 0 (Estrous - stage), day 8 (luteal-stage) and thought pregnancy stages, early (d 18-30), mid (d 60-90) and late (d 120-150). Also, some serum biochemical and trace elements were determined throughout pregnancy stages (early- mid and late). Serum was harvested after centrifugation at 5,000 $\mathrm{g}$. For 10 minutes, and then stored at $-20^{\circ} \mathrm{C}$ for later analysis.

\section{Hormonal assay}

Progesterone was analyzed using ELISA kit (Monobind, USA) according to Abraham, (1974). The intra -and inter-assay CV's are $(9.7 \%)$.

\section{Serum biochemical and trace elements metabolic analysis}

Serum samples from ewes during the experimental period were subjected to colorimetric analysis using commercial kits for the analysis of total protein (TP), albumin (Albu), globulin (Glo), total lipids (T.L), chole sterol (Cho), triglycerides (TG), urea, creatinine (Crea), aspartate amino transferase (AST), alanine aminotransferase (ALT) using commercial kits (Spectrum Biotechnology, Egypt). Phosphorous (P), calcium (Ca), selenium (Se), copper ( $\mathrm{Cu}$ ) and iron (Fe) were determined using (Inductively Coupled Argon Serum, iCAP 6500Duo, Thermo Scientific, England). The multi-element certified standard solution, Merch, Germany, was used as a stock solution for instrument standardization.

\section{Body weight of lambs}

Birth, monthly and weaning weights (90 days) were recorded using the digital balance.

\section{Statistical analysis}

Data of ewes and lambs' (birth and waning)weights, biochemical and trace elements metabolic concentrations were analyzed by the General Linear Model (GLM) procedure (SAS, 2006) using the following model:

$\mathrm{Y}_{\mathrm{ijk}}=\mu+\mathrm{G}_{\mathrm{i}}+\mathrm{S}_{\mathrm{j}}+\mathrm{G}^{*} \mathrm{Day}_{\mathrm{ij}}+\mathrm{e}_{\mathrm{ijk}}$

$Y_{i j k}=$ observations, $\mu=$ Overall means, $G_{i}=$ effect of $i^{\text {th }}$ group (i: $\left.1-3\right), S_{j}=$ effect of $j^{\text {th }}$ status $(j: 1-3), G^{*} S_{i j}=$ interaction between groups and status.

$\mathrm{e}_{\mathrm{ijk}}=$ Experimental error. Duncan's multiple range tests were used to separate means.

Another General Linear Model procedure (SAS, 2006) was used for the statistical analysis of birth and weaning weights and average daily gain for lambs using the following model:

$\mathrm{Y}_{\mathrm{ij}}=\mu+\mathrm{Ti}+\mathrm{e}_{\mathrm{ij}}$

$Y_{i j}=$ any observation of $j^{\text {th }}$ animal within the $i^{\text {th }}$ treatment

$\mu=$ Overall mean, $T_{i}=$ Effect of $i^{\text {th }}$ treatment $(i=1-3), e_{i j}=$ Experimental error

Data expressed as percentages included (conception rate, lambing rate, prolificacy rate, and sex ratio) were analyzed by the chisquared test.

\section{RESULTS AND DISCUSSION}

\section{Changes in blood serum progesterone profile}

Overall means of serum progesterone $\mathrm{P}_{4}$ concentrations of organic or inorganic-S groups $(6.38 \pm 0.48$ and $6.28 \pm 0.48$ $\mathrm{ng} / \mathrm{mL}$, respectively) were greater $(\mathrm{P}<0.01)$ than that of the control group $(4.36 \pm 0.48 \mathrm{ng} / \mathrm{mL})$ (Figure 1$)$. $\mathrm{P}_{4}$ concentrations were affected $(\mathrm{P}<0.01)$ by pregnancy stages. The lowest concentration of progesterone was recorded in day $0(0.18 \pm 0.78 \mathrm{ng} / \mathrm{mL})$ during $72 \mathrm{~h}$. of the $2^{\text {nd }}$ of $\mathrm{PGF}_{2 \alpha}$ injection (Estrous-stages), that the concentration increased to $(1.66 \pm 0.78 \mathrm{ng} / \mathrm{mL}) \mathrm{on}$ day 8 (luteal-Stage), and continued to reach $(10.00 \pm 0.78 \mathrm{ng} / \mathrm{mL})$ at day 90 (mid-stage), that declined to $(8.88 \pm 0.78 \mathrm{ng} / \mathrm{mL}) \mathrm{on} \mathrm{day}$ 150 (late-stage) (Figure.1). The interaction effect between treatment and pregnancy stages was not significant.

The increase observed in serum $\mathrm{P}_{4}$ concentration might be attributed to the increase of cholesterol concentration (Table 1), which is a precursor of $\mathrm{P}_{4}$ hormone synthesis (Abayasekara and Wathes, 1999). However, among different pregnancy stages, there was a significant increase in serum $\mathrm{P}_{4}$ concentrations in all experimental groups with the advancement of pregnancy stages. Similar findings were reported by Abd El-Hamid et al. (2016); Kandiel et al. (2016) in sheep and Abd El- Hamid et al. (2017) in goats. Progesterone concentration during pregnancy in sheep is a substantial contribution from the placenta-fetal unit (Linzell and Heap, 1968). It was reported that $P_{4}$ concentration in sheep serum during the first term of pregnancy is comparable to those found during the luteal- stage $\left(8 \mathrm{~d}\right.$ ) of the estrous cycle (Bazer and First, 1983) suggesting that corpus luteum is the main source of $\mathrm{P}_{4}$ to maintain pregnancy during this period. However, there was an increase in $\mathrm{P}_{4}$ concentration on early-stage (18-30 d) after mating which occurs in pregnant ewes (Bassett et al., 1969). The level of serum $\mathrm{P}_{4}$ is increased steadily in mid-stage of pregnancy (60-90 d), the placenta is the major source of $\mathrm{P}_{4}$ (Ricketts and Flint, 1980), and placental secretion of $\mathrm{P}_{4}$ during this stage is more than the ovarian contribution (Linzell and Heap. 1968). In late-stage (120-150 d) of pregnancy, serum $\mathrm{P}_{4}$ concentration was started to decline for preparation of the parturition process (Boulfekhar and Brudieux, 1980).

\section{Reproductive performance}

Our results showed that the conception rate increased $(\mathrm{P}<0.05)$ in organic and inorganic salts groups $(100 \%)$ compared with control $(91.67 \%)$. While lambing and prolificacy rates increased $(\mathrm{P}<0.05)$ in inorganic-S group (92.31 \& $100 \%$, 
respectively) compared with organic-S (85.71 \& $92.9 \%$, respectively) and control (83.33 \& 91.6\%, respectively). No significant difference was detected in the sex ratio of the experimental groups (Figure. 2).

It is well known that trace elements play important roles for fertility during the breeding season (Kumar, 2003). Our results, concerning the improvement of ewes' reproduction, were in agreement with studies in other species. Rodinova et al. (2008) reported that lambing rate of primiparous Sumavka ewes fed diet supplemented with selenium (Se) in organic or inorganic forms $(180 \mathrm{mg} / \mathrm{h} / \mathrm{d}$ of DM basis) during pregnancy period was improved compared with the control group. Moreover, Senosy et al. (2018) demonstrated that reproductive performance including a number of services/conceptions, pregnancy rate was significantly improved as a result of organic bound phosphorous injection twice a week for successive three weeks in Farafra ewes. Additionally, Phiri et al. (2007) found that reproductive performance was improved by calcium, phosphorus, and zinc supplementation in dairy cows' diets. Similar results were found in Merino ewes by master's and Fels (1980). These findings are in agreement with the present results and may be attributed to increase in numbers and sizes of ovarian follicles and size of corpora lutea (Senosy et al., 2018 and Dunn \& Moss, 1992), and enhance of antioxidants status by supplementation of Cu in the diet goats without producing any toxic signs, which led to decrease of reactive nitrogen species (RNS) and reactive oxygen species (ROS), thus improve of reproductive characteristics (Yoshikawa and Naito, 2002). These results are supported by data of serum phosphorus, copper levels presented in (Figure 3).

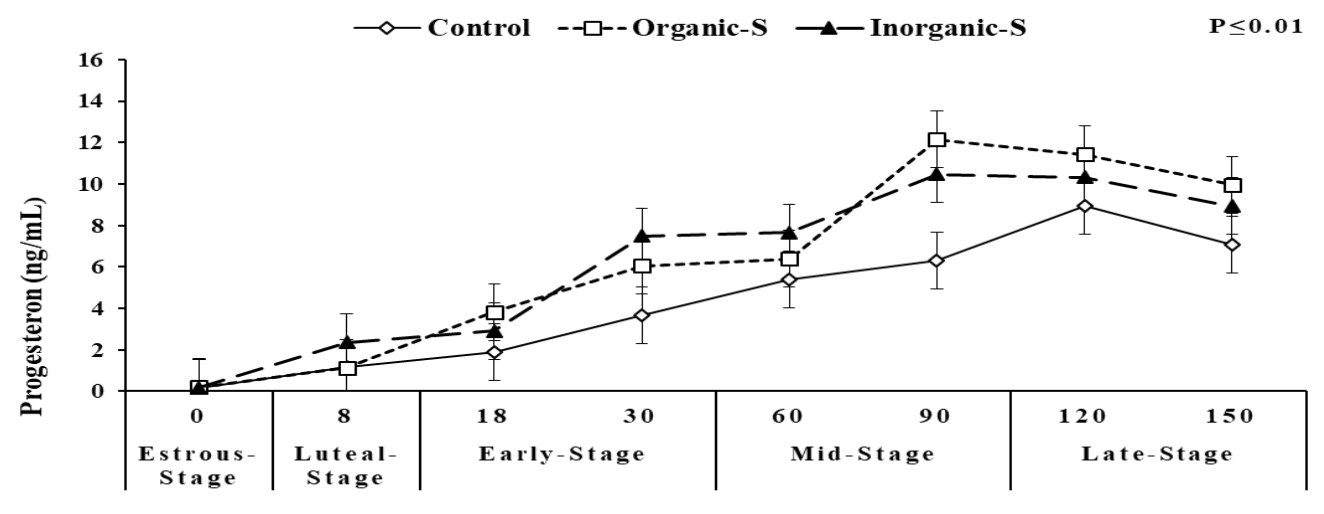

pregnancy stages

Figure 1: Changes in serum progesterone $\left(P_{4}\right)$ concentrations in Aboudeleik ewes during pregnancy at days $(0 d=E s t r o u s-$ stage, $8 \mathrm{~d}=$ Luteal-stage, 18-30d= Early-stage, 60-90d=Mid-stage and 120-150d=Late-stage of pregnancy.

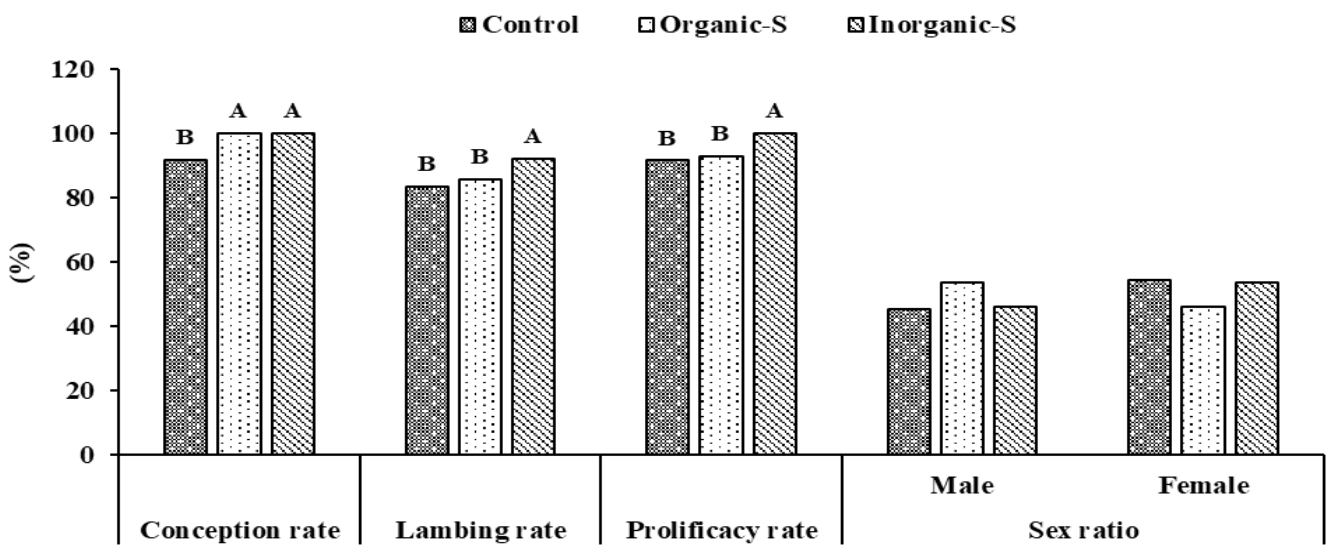

Figure 2: Percentages of reproductive performance including conception, lambing prolificacy rates, and sex ratio of Aboudeleik ewes fed a control diet or a diet supplemented with trace-elements in organic or inorganic forms.

${ }^{\mathrm{A}-\mathrm{B}}$ letters among groups differ significantly $(\mathrm{P}<0.05)$.

- Conception rate $=$ a number of ewes conceived / number of ewes showing estrus and mated $\times 100$

- Lambing rate $=$ number of ewes lambed $/$ number of ewes mated $\times 100$.

- Prolificacy rate $=$ number of lambs born/number ewes lambed $\times 100$.

Changes in serum biochemical constituents

Overall means of serum total proteins (TP, g/dL), albumin (Albu, g/dL), globulin (Glo, g/dL), urea (mg/dL) and serum aspartate (AST) and alanine (ALT) aminotransferase levels did not differ significantly among experimental groups due to treatment, stage of pregnancy and the interaction between them (Table 2).

It is worthy of mentioning that our values were within the reference values (Table 2) during different stages of pregnancy in ewes under arid condition (El-Sherif and Assad, 2001).

The obtained resulted demonstrated that control group had higher $(\mathrm{P}<0.05)$ serum creatinine $(\mathrm{Crea}, \mathrm{mg} / \mathrm{dL})$ concentration $(2.16 \pm 0.09 \mathrm{mg} / \mathrm{dL})$ than those for organic or inorganic-S groups $(1.98 \pm 0.09,1.83 \pm 0.09 \mathrm{mg} / \mathrm{dL}$, respectively). However, the stage of pregnancy or the interaction between treatment and pregnancy stage didn't reveal any significant effects on serum creatinine concentration (Table 2). 
Citation: Abd El-Hamid, I, S. et al., Influence of organic or inorganic forms of salts rich in phosphors, copper and zinc on reproduction, productivity and blood constituents in sheep. Australian Journal of Basic and Applied Sciences, 13(6): 14-22. DOI: 10.22587/ajbas.2019.13.6.2

Higher serum creatinine in control group was previously observed in the arid zones because of nutritional deprivation, lack of natural pasture protein, water restriction, stress (Ndlovu et al., 2009; Abdel-Fattah, 2008 and Thrall et al., 2004). However, phosphorous administration as trace element led to decrease the serum creatinine. As a result, to improve nitrogen utilization (Senosy et al., 2018). On the other hand, supplemented groups had higher $(\mathrm{P}<0.05)$ overall means of serum total lipids concentration (T.L, $\mathrm{mg} / \mathrm{dL})$ than the control group with values being $(655.32 \pm 52.58,648.83 \pm 52.58$ and $557.29 \pm 52.58 \mathrm{mg} / \mathrm{dL})$ for organic, inorganic and control groups, respectively. Serum total lipids concentrations were affected $(\mathrm{P}<0.01)$ by pregnancy stages where the highest values were recorded at late and mid stages $(732.42 \pm 52.58$ and $644.90 \pm 0.52 .58 \mathrm{gm} / \mathrm{dL}$, respectively), while the lowest value was recorded in early stage $(484.13 \pm 52.58 \mathrm{gm} / \mathrm{dL})$. There was no significant effect due to the interaction between treatment and pregnancy stages. The overall means of serum cholesterol $(\mathrm{Cho}, \mathrm{mg} / \mathrm{dL})$ concentration was increased $(\mathrm{P}<0.05)$ in ewes fed diet supplemented with organic or inorganic salts $(72.73 \pm 2.64$ and $69.75 \pm 2.64 \mathrm{mg} / \mathrm{dL}$, respectively) as compared to control group $(59.73 \pm 2.64 \mathrm{mg} / \mathrm{dL})$ (Table 2). Stages of pregnancy and the interaction between treatment and pregnancy stares didn't affect serum cholesterol concentration significantly. The same trend was noted in the overall mean of serum triglycerides concentration (TG, mg/dL) Table (2).

Similar findings were reported in different Species in lambs (Cheng et al., 2008) and goats (Zhang et al., 2012) or in goat kids (Datta et al., 2007 and Mondala et al., 2007). In our results the serum cholesterol concentration (Cho) increased, those results are in agreement with (Amer et al., 1973 and Abdel-Mageed et al., 1990). Regulation of cholesterol synthesis in ruminants is controlled with many factors, such as animal's antioxidant status especially glutathione peroxidase (GSH) and diets content of trace elements (Panev et al., 2013), which are mainly related to activity of the enzyme 3-hydroxy-3-methyl-glutaryl coenzyme A (HMG-CoA) in tissues, increased intestinal secretion of lipoproteins with higher contents of triglycerides led to increase in Cho concentration (Starry, 1981).

Table 2. Least square means $\pm \mathrm{SE}$ of Serum biochemical concentrations of pregnant Aboudeleik ewes fed a control diet or

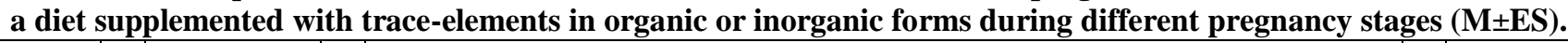

\begin{tabular}{|c|c|c|c|c|c|c|c|c|c|c|}
\hline \multirow{2}{*}{ Items } & \multirow{2}{*}{ Groups } & \multicolumn{6}{|c|}{ Days of pregnancy period } & \multicolumn{3}{|c|}{ Pvalue } \\
\hline & & $\begin{array}{c}\text { Early-stage } \\
(18-30 \mathrm{~d})\end{array}$ & $\begin{array}{r}\text { Mid-stage } \\
(60-90 \mathrm{~d})\end{array}$ & $\begin{array}{l}\text { Late-stage } \\
(120-150 \mathrm{~d})\end{array}$ & $\pm \mathrm{SE}$ & Overall & $\pm \mathrm{SE}$ & G & $\mathrm{S}$ & $\mathrm{G} \times \mathrm{S}$ \\
\hline \multirow{4}{*}{$\begin{array}{l}\text { TP } \\
(\mathrm{g} / \mathrm{dL})\end{array}$} & Control & 6.32 & 5.91 & 6.03 & \multirow{3}{*}{0.32} & 6.09 & \multirow{3}{*}{0.18} & \multirow{3}{*}{0.20} & \multirow{3}{*}{0.40} & \multirow{3}{*}{0.31} \\
\hline & Organic-S & 6.33 & 5.62 & 6.27 & & 6.07 & & & & \\
\hline & Inorganic-S & 5.79 & 5.98 & 5.19 & & 5.65 & & & & \\
\hline & Overall & 6.15 & 5.83 & 5.83 & 0.18 & & & & & \\
\hline \multirow{3}{*}{$\begin{array}{l}\text { Alb } \\
(\mathrm{g} / \mathrm{dL})\end{array}$} & Control & 4.76 & 4.62 & 4.59 & \multirow{3}{*}{0.44} & 4.65 & \multirow{3}{*}{0.25} & \multirow{3}{*}{0.60} & \multirow{3}{*}{0.20} & \multirow{3}{*}{0.48} \\
\hline & Organic-S & 3.76 & 4.36 & 4.93 & & 4.35 & & & & \\
\hline & Inorganic-S & 3.81 & 4.35 & 3.74 & & 3.97 & & & & \\
\hline \multirow{4}{*}{$\begin{array}{l}\text { Glo } \\
\text { (g/dL) }\end{array}$} & Overall & 4.11 & 4.44 & 4.42 & 0.25 & & & & & \\
\hline & Control & 1.56 & 1.29 & 1.44 & \multirow{3}{*}{0.43} & 1.34 & \multirow{3}{*}{0.24} & \multirow{3}{*}{0.14} & \multirow{3}{*}{0.68} & \multirow{3}{*}{0.66} \\
\hline & Organic-S & 2.56 & 1.26 & 1.33 & & 1.72 & & & & \\
\hline & Inorganic-S & 1.98 & 1.62 & 1.44 & & 1.68 & & & & \\
\hline \multirow{4}{*}{$\begin{array}{l}\text { T.L } \\
(\mathrm{mg} / \mathrm{dL})\end{array}$} & Overall & 2.03 & 1.39 & 1.40 & 0.24 & & & & & \\
\hline & Control & 510.65 & 483.54 & 677.68 & & $557.29^{\mathrm{B}}$ & & & & \\
\hline & Organic-S & 401.12 & 633.98 & 900.88 & 91.07 & $655.32^{\mathrm{A}}$ & 52.58 & 0.05 & 0.01 & 0.07 \\
\hline & Inorganic-S & 540.61 & 787.17 & 618.70 & & $648.83^{\mathrm{A}}$ & & & & \\
\hline & Overall & $484.13^{Y}$ & $732.42^{X}$ & $644.90^{x}$ & 52.58 & & & & & \\
\hline Cho & Control & 51.93 & 66.96 & 60.31 & & $59.73^{\mathrm{c}}$ & & & & \\
\hline$(\mathrm{mg} / \mathrm{dL})$ & Organic-S & 72.13 & 77.46 & 68.83 & 4.58 & $72.73^{\mathrm{A}}$ & 2.64 & 0.05 & 0.33 & 0.62 \\
\hline & Inorganic-S & 74.39 & 72.42 & 62.46 & & $69.75^{\mathrm{B}}$ & & & & \\
\hline & Overall & 66.15 & 72.28 & 63.86 & 4.58 & & & & & \\
\hline $\mathrm{TG}$ & Control & 39.67 & 31.38 & 24.88 & & $31.97^{\mathrm{C}}$ & & & & \\
\hline$(\mathrm{mg} / \mathrm{dL})$ & Organic-S & 56.78 & 39.34 & 65.68 & 8.77 & $53.97^{\mathrm{A}}$ & 10.13 & 0.05 & 0.33 & 0.87 \\
\hline & Inorganic-S & 37.30 & 31.87 & 64.41 & & $44.52^{\mathrm{B}}$ & & & & \\
\hline & Overall & 44.58 & 34.19 & 51.65 & 10.13 & & & & & \\
\hline Urea & Control & 60.10 & 44.14 & 50.06 & & 51.43 & & & & \\
\hline$(\mathrm{mg} / \mathrm{dL})$ & Organic-S & 45.08 & 54.86 & 51.02 & 4.26 & 50.32 & 2.46 & 0.65 & 0.53 & 0.07 \\
\hline & Inorganic-S & 56.81 & 54.09 & 49.69 & & 53.53 & & & & \\
\hline & Overall & 53.99 & 51.03 & 50.25 & 2.46 & & & & & \\
\hline & Control & 2.48 & 2.14 & 1.87 & & $2.16^{\mathrm{A}}$ & & & & \\
\hline Crea & Organic-S & 1.87 & 2.01 & 2.05 & 0.15 & $1.98^{\mathrm{AB}}$ & 0.09 & 0.05 & 0.86 & 0.10 \\
\hline & Inorganic-S & 1.73 & 1.80 & 1.96 & & $1.83^{\mathrm{B}}$ & & & & \\
\hline & Overall & 2.03 & 1.98 & 1.96 & 0.09 & & & & & \\
\hline & Control & 57.97 & 68.66 & 79.86 & & 68.83 & & & & \\
\hline AST & Organic-S & 71.84 & 77.32 & 68.52 & 5.88 & 72.56 & 3.39 & 0.44 & 0.68 & 0.10 \\
\hline (IU/L) & Inorganic-S & 71.81 & 61.47 & 65.79 & & 66.35 & & & & \\
\hline & Overall & 67.21 & 69.15 & 71.39 & 3.39 & & & & & \\
\hline & Control & 78.94 & 73.67 & 86.05 & & 79.40 & & & & \\
\hline ALT & Organic-S & 79.56 & 87.88 & 82.71 & 8.07 & 83.38 & 4.66 & 0.54 & 0.95 & 0.75 \\
\hline (IU/L) & Inorganic-S & 90.13 & 85.87 & 84.47 & & 86.82 & & & & \\
\hline & Overall & 82.73 & 82.47 & 84.41 & 4.66 & & & & & \\
\hline
\end{tabular}

${ }^{A-C}$ values with different superscript letters in the same column are statistically different $(\mathrm{P}<0.05)$.

${ }^{\mathrm{X}-\mathrm{Y}}$ values with different superscript letters in the same rows are statistically different $(\mathrm{P}<0.05)$. 
Citation: Abd El-Hamid, I, S. et al., Influence of organic or inorganic forms of salts rich in phosphors, copper and zinc on reproduction, productivity and blood constituents in sheep. Australian Journal of Basic and Applied Sciences, 13(6): 14-22. DOI: 10.22587/ajbas.2019.13.6.2

\section{Changes in serum mineral concentrations during pregnancy stages}

The present results showed that G3 (inorganic-S) achieved the highest overall mean values of serum calcium $(0.81 \pm 0.15$ $\mathrm{mg} / \mathrm{dL})$ followed by control and organic-S, respectively $(0.72 \pm 0.15$ and $0.50 \pm 0.15, \mathrm{mg} / \mathrm{dL})$. However, the difference due to treatment, stages of pregnancy and the interaction between them were not significant. Serum selenium concentrations demonstrated that treated ewes had exceeded their counterparts of control ones with values being $10.32 \pm 0.70,8.73 \pm 0.70$ and $8.64 \pm 0.70 \mathrm{mg} / \mathrm{dL}$ for and inorganic-S, organic-S and control groups in order. No significant differences among treatment groups or stages of pregnancy were recorded. Furthermore, the interaction between treatment and pregnancy stages was not significant. The same trend was found in the overall means of serum iron concentrations inorganic-S group recorded the highest value $(60.22 \pm 0.90, \mathrm{mg} / \mathrm{dL})$ followed by organic-S group $(52.44 \pm 0.90, \mathrm{mg} / \mathrm{dL})$ which the lowest Fe concentration was recorded for the control group $(47.83 \pm 0.90, \mathrm{mg} / \mathrm{dL})$. There were no significant effects of pregnancy stages and the interaction between pregnancy stages and treatments (Figure 3). The overall means of serum phosphorus concentration declared that organic-S group had higher $(\mathrm{P}<0.01)$ value of $\mathrm{P}(5.23 \pm 0.29 \mathrm{mg} / \mathrm{dL})$ than the control or inorganic-S groups $(2.37 \pm 029$ and $3.72 \pm 0.29 \mathrm{mg} / \mathrm{dL}$ respectively $)$. Pregnancy stages and the interaction between treatment and stages of pregnancy didn't have any significant effects on P values. The present findings revealed that serum copper $(\mathrm{Cu})$ concentration took the same pattern of $\mathrm{P}$ inorganic-S group had the highest $\mathrm{Cu}$ value $(3.42 \pm 0.40, \mathrm{mg} / \mathrm{dL}$, respectively) compared with control ones $(1.84 \pm 0.40 \mathrm{mg} / \mathrm{dL})$ (Figure 3$)$. The differences among groups were significant $(\mathrm{P}<0.01)$. However, the difference due to pregnancy stages and the interaction between treatment and pregnancy stages were not significant (Figure. 3).

These findings are in agreement with previous reports in different animal species, in sheep (Senosy et al., 2018; Abdelrahman et al., 2017 and Jalilian et al., 2012), in goats (Pechova et al., 2009), in kids goats (Strnadová et al., 2011; Palenikova et al., 2014), in dairy cows (Kinal et al., 2007). Increasing of serum concentration of phosphorus and copper are due to supplementation of microelements with the bioavailability of microorganisms in rumen led to better transfer of trace elements to the tissues, including blood (Spears, 1996; Olson et al., 1999; Huert et al., 2002).
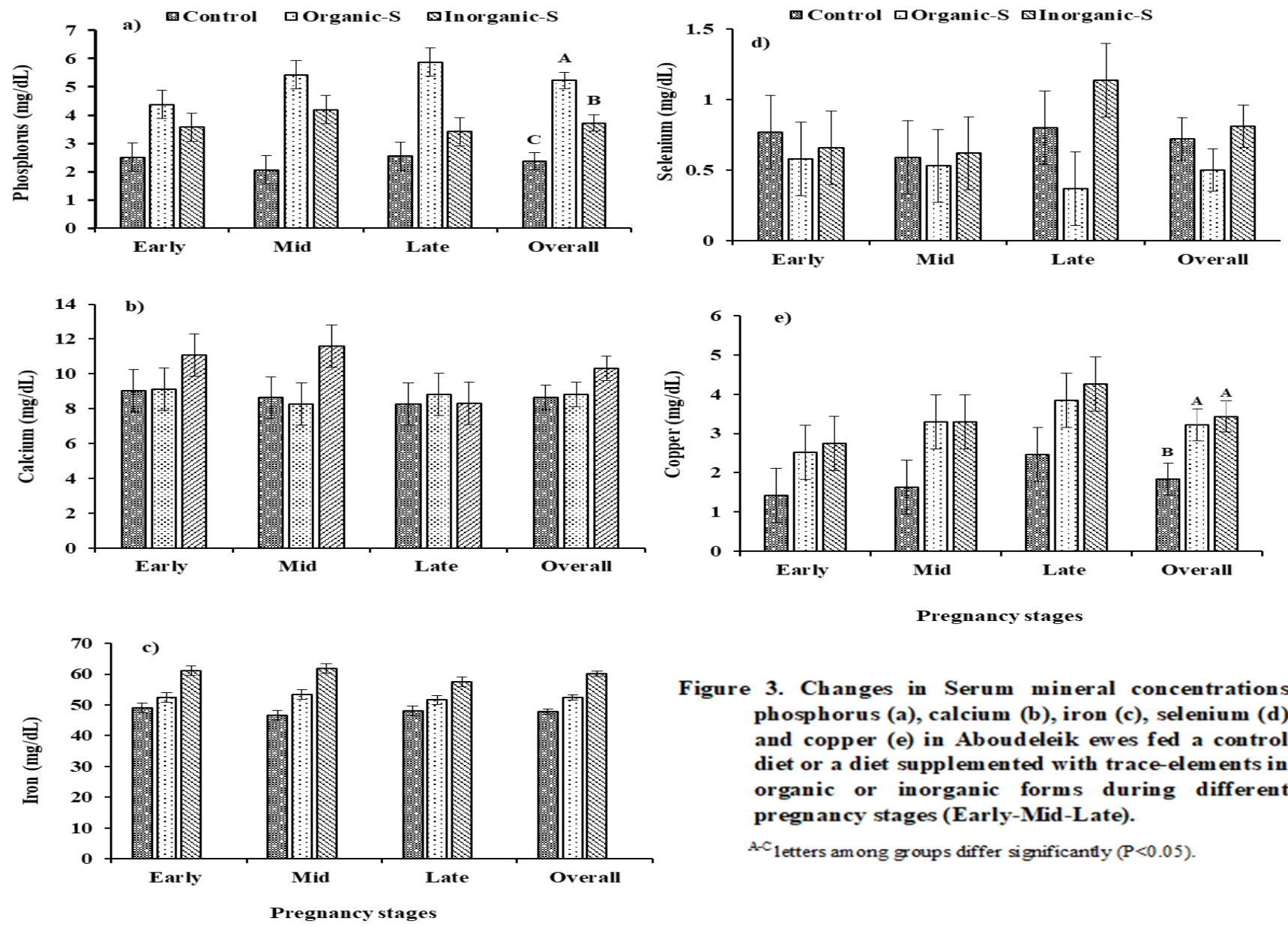

Figure 3. Changes in Serum mineral concentrations phosphorus (a), calcium (b), iron (c), selenium (d) and copper (e) in Aboudeleik ewes fed a control diet or a diet supplemented with trace-elements in organic or inorganic forms during different pregnancy stages (Early-Mid-Late).

A-c 1 etters among groups differ significantly $(P<0.05)$.

\section{Productive traits of newly born lambs}

Birth weight for lambs born from ewes supplemented with organic salts was higher $(\mathrm{P}<0.05)(2.89 \pm 0.12 \mathrm{~kg})$ than lambs born from ewes supplemented with inorganic-S $(2.72 \pm 0.11 \mathrm{~kg})$ or control ewes $(2.49 \pm 0.12 \mathrm{~kg})$. No significant effect of treatment $\times$ time interaction was observed on lamb's body weights. Concerning the values of weaning weight and average daily gain, the present results demonstrated that lambs born from ewes supplemented with organic and inorganic salts achieved higher $(\mathrm{P}<0.05)$ weaning weight $(15.30 \pm 0.64,14.54 \pm 0.62 \mathrm{Kg}$, respectively) and average daily gain $(137.5 \pm 0.01,130.8 \pm 0.01 \mathrm{gm}$, respectively) compared with lambs born from control ewes $(12.58 \pm 0.67 \mathrm{Kg}$ and $111.7 \pm 0.01 \mathrm{gm})$ (Table 3). 
Citation: Abd El-Hamid, I, S. et al., Influence of organic or inorganic forms of salts rich in phosphors, copper and zinc on reproduction, productivity and blood constituents in sheep. Australian Journal of Basic and Applied Sciences, 13(6): 14-22. DOI: 10.22587/ajbas.2019.13.6.2

Average body weight of kids born to goat dams fed (30 $\mathrm{mg} \mathrm{Cu} / \mathrm{kg} \mathrm{DM})$ inorganic or organic forms were higher (Palenikova et al., 2014; Solaiman et al., 2007). Moreover, kids supplemented (60 mg Zn/ kg DM) organic or inorganic forms with diets showed significantly higher average daily gain compared with control (Strnadová et al., 2011). While growth performance of (Dorper $\times$ Mongolia) lambs fed $(10$ or $20 \mathrm{mg} \mathrm{Cu} / \mathrm{kg} \mathrm{DM}$ ) to the basal diet did not differ (Cheng et al., 2008). The present results revealed that growth performance increased significantly towards the end of lactation period ( 3 month). It has been documented that, newborn of lambs is dependent upon their dams for transfer of these nutrients via the placenta and the mammary gland (Rock et al., 2001; Jalilian et al., 2012). Furthermore, the highest growth rate and waning weight of lambs during the first three months of life, are affected by many factors such as number of lambs born per ewe (Datta et al., 2007), improved of immunity to newly born from dams feeding with by $\mathrm{P}, \mathrm{Cu}$ and $\mathrm{Zn}$ in organic or inorganic forms (Senosy et al., 2018; Strnadová et al., 2011). Supplementation of trace elements had a positive impact on quality milk or milk fat content (Antunovic et al., 2017; Kinal et al., 2007; Wiking et al., 2008; Pechova et al., 2009). After the first few months the newborn became progressively less dependent on the mother milk, as its consumption of solid food increase (Owen. 1976). Huang et al. (2014) reported that supplementation of higher $\mathrm{Cu}$ led to positive changes in intramuscular fat content (PUSFA), meat growth, carcass characteristics and meat quality of goat kids. However, the mechanism of improvement is unknown.

Table 3. Productive traits of newly born lambs' born from Aboudeleik fed a basic diet or supplemented with trace elements in organic or inorganic forms during the early lactation period $(\mathrm{LSM} \pm \mathrm{SE})$.

\begin{tabular}{|c|c|c|c|c|}
\hline \multirow{2}{*}{ Traits } & \multicolumn{3}{|c|}{ Treatments } & \multirow{2}{*}{$P$ value } \\
\hline & Control & Organic-S & Inorganic-S & \\
\hline Birth weight (kg) & $2.49^{\mathrm{B}} \pm 0.12$ & $2.89^{\mathrm{A}} \pm 0.12$ & $2.72^{\mathrm{AB}} \pm 0.11$ & \\
\hline Weaning weight (Kg) & $12.58^{\mathrm{B}} \pm 0.67$ & $15.30^{\mathrm{A}} \pm 0.64$ & $14.54^{\mathrm{A}} \pm 0.62$ & 0.05 \\
\hline Average daily gain (gm) & $111.7^{\mathrm{B}} \pm 0.01$ & $137.5^{\mathrm{A}} \pm 0.01$ & $130.8^{\mathrm{A}} \pm 0.01$ & \\
\hline
\end{tabular}

A-B values within the same row with different letters differ $(\mathrm{P}<0.05)$.

\section{CONCLUSIONS}

It could be concluded that the salts rich in phosphorus, copper and zinc in organic or inorganic forms supplemented to Aboudeleik ewes during different pregnancy stages increased serum progesterone profile, blood lipid metabolites including total lipids, cholesterol and triglycerides concentrations and serum phosphorus, copper concentrations. Reproductive performance including (conception, prolificacy and lambing rates) and productive traits of newly born lambs including Birth, weaning weights and average daily gain were improved.

\section{ACKNOWLEDGMENT}

The authors are thankful to Mrs. Eman A. Noman, Assistant Researcher at Desert Research Center, for her assistance with the determination of biochemical blood parameters. Our sincere thanks and gratitude go to Prof. Dr. Yousri M. Shaker for helpful comments in editing the manuscript.

\section{REFERENCES}

Abayasekara DRE \& Wathes DC (1999) Effects of altering dietary fatty acid composition on prostaglandin synthesis and fertility. Journal of Prostaglandins, Leukotrienes and Essential fatty Acids 61, 275- 287.

Abd El-Hamid IS, Ibrahim NH, Farrag B, Younis FE \& Wahba IA (2017) Reproductive and productive efficiency of Damascus and Baladi goats under Egyptian arid conditions. Research Journal of Animal and Veterinary Sciences9, 6- 14.

Abd El-Hamid IS, Nour El-Din ANM, Zaghloul AA, El-Bahrawy KA, Elshahaw II, Allam AM, EL-Zarkouny SZ \& Hassan GA (2016) Effects of calcium salts of fatty acids rich in palmitic and oleic fatty acids on reproduction and serum biochemistry in Barki ewes. Small Ruminant Research144, 113-118.

Abdel-Fattah MS, Azamel AA \& Ibrahim KMA (2008) Water balance and body fluids distribution of Barki lambs fed Kochia indica in Sinai. Journal of Agricultural Science Mansoura University 33, 5595-5609.

Abdel-Mageed AB \& Oehme FW (1990) A review of the biochemical roles, toxicity and interactions of zinc, copper and iron: II. Copper. Veterinary and Human Toxicology 32, 230-234.

Abdelrahman MM, Aljumaah RS \& Khan, RU (2017) Effects of prepartum sustained-release trace elements ruminal bolus on performance, colostrum composition and blood metabolites in Najdi ewes. Environmental Science and Pollution Research24, 9675-9680.

Abou El-Ezz, SS \&Younis, FE (2010) Salt and Trace Minerals for Livestock and Other Animals. Eighth Scientific Conference of Society of Physiological Sciences and their Applications, at Sharm El-Sheik

Abraham GE (1974) Ovarian and adrenal contribution to peripheral androgens during the menstrual cycle. Journal Clin Endocrinol Metabolism 39, 340 - 346.

Aliarabi H, Fadayifar A, Alimohamady R \& Dezfoulian AH (2019) The Effect of Maternal Supplementation of Zinc, Selenium, and Cobalt as Slow-Release Ruminal Bolus in Late Pregnancy on Some Blood Metabolites and Performance of Ewes and Their Lambs. Biological Trace Element Research 187, 403-410. 
Citation: Abd El-Hamid, I, S. et al., Influence of organic or inorganic forms of salts rich in phosphors, copper and zinc on reproduction, productivity and blood constituents in sheep. Australian Journal of Basic and Applied Sciences, 13(6): 14-22. DOI: 10.22587/ajbas.2019.13.6.2

Amer MA, Laurent, ST \& Brisson GJ (1973) Supplemental copper and selenium for calves: effects upon ceruloplasmin activity and liver copper concentration. Canadian Journal of Physiology and Pharmacology 51, 649-653.

Antunovic Z, Novoselec J, Šperanda M, Steiner Z, Ćavar S, Pavlović N, Lendić KV, Mioč B, Paćinovski N \& Klir Ž (2017) Monitoring of blood metabolic profile and milk quality of ewes during lactation in organic farming. Mljekarstvo 67, 243252.

Badawy N. S, Abdou A S \& El-Rayes MA-H (2018) Studies on the effect of some salt additives on the skin and coat characteristics of sheep in Hederba valley ranges. Egyptian Journal Nutrition and Feeds21, 81-92.

Bassett JM, Oxborrow TJ, Smith ID \& Thorburn GD (1969) The concentration of progesterone in the peripheral plasma of the pregnant ewe. Journal of Endocrinology 45, 449 - 457.

Bazer FW \& First NL (1983) Pregnancy and parturition. Journal of Animal Science 57, 425 - 460.

Boldizarova K, Gresakova L, Faix S, Mellen M \& Leng L (2005) Antioxidant status of lambs fed on diets sup supplemented with selenite or Se-yeast. Journal of Animal and Feed Sciences14, 245-253.

Boulfekhar L \& Brudieux R (1980) Peripheral concentrations of progesterone, cortisol, aldosterone, sodium and potassium in the plasma of the Tadmit ewe during pregnancy and parturition. Journal of Endocrinology 84, 25 - 33.

Cheng J.B, Fan CY, Zhu, XP, Zhang W, Yan, XG, Wang, RL \& Jia, ZH (2008) Effects of dietary copper source and level on performance, carcass characteristics and lipid metabolism in lambs. Asian Australas Journal of Animal Science 21, 685-691.

Datta C, Mondal MK \& Biswas P (2007) Influence of dietary inorganic and organic form of copper salt on performance, serum lipids and nutrient utilization of Black Bengal (Capra hircus) goat kids. Animal Feed Science and Technology 135, $191-209$.

Davis KG \& Mertz W (1987) Copper. In: Mertz W (ed) Trace elements in human and animal nutrition. Academic Press, N.Y.

Desert Research Center (1996) Development of Animal Wealth in Shalateen, Aburamad and Halaieb. First progress Report, March Desert Research Center, Cairo, Egypt, pp. 17.

Dunn TG \& Moss GE (1992) Effects of nutrient deficiencies and excesses on reproductive efficiency of livestock. Journal of Animal Science70, 1580-1593.

El-Shaer HM, Kandil HM, Abou El-Nasr H.M \& Khamis HS (1997) Features and constrains of animal resources development in Shalateen- Halaieb region. Egyptian Journal Nutrition and feeds (Special Issue), 121-128.

El-Sherif MMA \& Assad F (2001) Changes in some blood constituents of Barki ewes during pregnancy and lactation under semiarid condition. Small Ruminant Research 40, 269-277.

Hays VW \& Swenson MJ (1985) Minerals and Bones. In: Dukes'Physiology of Domestic Animals 1985; Tenth Edition pp. 449466.

Huang Y, Wang Y, Lin X and \& Guo, C (2014) Effects of Supplemental Copper on the Serum Lipid Profile, Meat Quality, and Carcass Composition of Goat Kids. Biological Trace Element Research 159, 140-146.

Huert M, Kincaid RL, Cronrath JD, Busboom J, Johnson AB \& Swenson CK (2002) Interaction of dietary zinc and growth implants on weight gain, carcass traits and zinc in tissues of growing beef steers and heifers. Animal Feed Science and Technology 95, 15-32.

Hylland K, Ruus A, Grung M \& Green N (2009) Relationships between physiology, tissue contaminants, and biomarker responses in Atlantic Cod (Gadus morhua L.). Journal of Toxicol. Environ. Health72, 226-233.

Jalilian MT, Moeini MM \& Karkodi K (2012) Effect of selenium and vitamin E supplementation during late pregnancy on colostrum and plasma $\mathrm{Se}, \mathrm{Cu}, \mathrm{Zn}$ and Fe concentrations of fat tail Sanjabi ewes and their lambs. Acta Argiculturae Slovenica 100, 123-129.

Jou MY, Philipps AF\& Lonnerdal B (2010) Maternal zinc deficiency in rats affects growth and glucose metabolism in the offspring by inducing insulin resistance postnatally. Journal of Nutrition 20, 1621-1627.

Kadim IT, Mahgoub O, Al-Ajmi DS, Al-Maqbaly RS, Al-Saqri NM \& Ritchie A (2003) An evaluation of the growth, carcass and meat quality characteristics of Omani goat breeds. Meat Science 66, 203-210.

Kandiel MMM, El-Khaiat HM \& Karima MM (2016) Changes in some hematobiochemical and hormonal profile in Barki sheep with various reproductive statuses. Small Ruminant Research 136, 87-95.

Khalil MH, Khalifa HH, El-Gabbas, HH \& Abdel-Fattah, MSH (1990) The adaptive responses to water deprivation in local and crossbred sheep. Egyptian Journal Animal Production 27, 195-215.

Kim YY \& Mahan DC (2001) Effects of high dietary levels of selenium-enriched yeast and sodium selenite on macro and micro mineral metabolism in grower-finisher swine. Asian-Australasian Journal of Animal Sciences 14, $243-249$.

Kinal S, Korniewicz A, Słupczyńska M, Bodarski R, Korniewicz D \&Čermak B (2007) Effect of the application of bioplexes of zinc, copper and manganese on milk quality and composition of milk and colostrum and some indices of the blood metabolic profile of cows. Czech Journal of Animal Science Agricultural Journals 52, 423-429.

King JC (2000) Determinants of maternal zinc status during pregnancy. American Journal of Clinical Nutrition71, $1334-1343$.

Krajnicakova ME, Bekeova E, Kovac GM, kostecky I, Valocky, I, Maracek I, Sutiakova I \& Lenhardt L (2003) Selected clinicalbiochemical parameters in the puerperal period of goats. Bulletin of the Veterinary Institute Pulawy 47, 177-182.

Kumar S (2003) Management of infertility due to mineral deficiency in dairy animals. In: Proceedings of ICAR summer school on "Advance diagnostic techniques and therapeutic approaches to metabolic and deficiency diseases in dairy animals". Held at IVRI, Izatnagar, UP (15 ${ }^{\text {th }}$ July to $4^{\text {th }}$ Aug.) pp: $128-137$.

Linzell JL \& Heap RB (1968) A comparison of progesterone metabolism in pregnant sheep and goats: Source of production and estimation of uptake by some target organs. Journal of Endocrinology 41, 338 - 433.

Masters DG \& Fels HE (1980) Effect of zinc supplementation on the reproductive performance of grazing merino ewes. Biological Trace Element Research 2, 281-290. 
Citation: Abd El-Hamid, I, S. et al., Influence of organic or inorganic forms of salts rich in phosphors, copper and zinc on reproduction, productivity and blood constituents in sheep. Australian Journal of Basic and Applied Sciences, 13(6): 14-22. DOI: 10.22587/ajbas.2019.13.6.2

McArdle HJ, Andersen HS, Jones H \& Gambling, L (2006) Fetal programming: causes and consequences as revealed by studies of dietary manipulation in rats - a review. Placenta 27, 56-60.

Mondala MK, Biswas P, Roya B \& Mazumdarb D (2007) Effect of copper sources and levels on serum lipid profiles in Black Bengal (Capra hircus) kids. Small Ruminant Research 67, 28-35.

Ndlovu T, Chimonyo M, Okoh AI, Muchenje V, Dzama K, Dube S \& Raats JG (2009) A comparison of nutritionally-related blood metabolites among Nguni, Bonsmara and Angus steers raised on sweetveld. Veterinary Journal 179, $273-281$.

Olson PA, Brink DR, Hickok DT, Carlson MP, Schneider NR, Deutscher GM, Adams DC, Colburn DJ \& Johnson AB (1999) Effects of supplementation of organic and inorganic combinations of copper, cobalt, manganese and zinc above nutrient requirement levels on postpartum two-year-old cows. Journal of Animal Science 77, 522-532.

Owen JB (1976) Sheep production; Bailliere Tindall, London, UK.

Palenikova I, Hauptmanova K, Pitropovska, E, Palenik T, Husakova T, Pechova A \& Pavlata L (2014) Copper metabolism in goat-kid relationship at supplementation of inorganic and organic forms of copper. Czech Journal of Animal Science Agricultural Journals 59, 201-207.

Panev A, Hauptmanová K, Pavlata L, Pechová A, Filípek J \& Dvořák R (2013) Effect of supplementation of various selenium forms and doses on selected parameters of ruminal fluid and blood in sheep. Czech Journal of Animal Science Agricultural Journals 58, 37-46.

Pechova A, Pavlata L, Dvorak, R \& Lokajova, E (2009) The concentrations of $\mathrm{Zn}, \mathrm{Cu}, \mathrm{Mn}$ and Se in milk in relation to the concentration of microelements in blood, daily milk and stage of lactation in dairy cattle. Acta Veterinaria Brno 77, 523-531.

Phiri EC, Nkya R, Pereka AE, Mgasa, MN \& Larsen T (2007) The effects of calcium, phosphorus and zinc supplementation on reproductive performance of crossbred dairy cows in Tanzania. Tropical Animal Health and Production 39, 317-723.

Quirk M \& Norton B (1987) The relationship between the cobalt nutrition of ewes and the vitamin $B_{12}$ status of ewes and their lambs. Crop and Pasture Science 38, 1071-1082.

Ricketts AP \& Flint APF (1980) Onset of synthesis of progesterone by ovine placenta. Journal of Endocrinology 86, 337 - 347.

Rock M, Kincaid R \& Carstens, G (2001) Effects of prenatal source and level of dietary selenium on passive immunity and the metabolism of newborn lambs. Small Ruminant Research 40, 129-138.

Rodinova H, Kroupova V, Travnicek J, Stankova M \& Pisek L (2008) Dynamics of IgG in the blood serum of sheep with different selenium intake. Veterinarni Medicina53, 260-265.

Samir AE (1990) Metabolic disorders among sheep reared in Behera government. M.Sc. Thesis; Fac. of Veter. Medi. Alex. Univ.

SAS Institute Inc (2006) Base SAS 9.1.3 Procedures Guide, Second Edition. SAS Institute Inc., Cary, NC.

Senosy W, Kassab AY, Hamdon HA \& Mohammed AA (2018) Influence of organic phosphorus on reproductive performance and metabolic profiles of anoestrous Farafra ewes in subtropics at the end of breeding season. Reproductive Domestic Animals 53, 904-913.

Solaiman SG, Craig JR, Reddy G \& Shoemaker CE (2007) Effect of high levels of Cu supplement on growth performance, rumen fermentation, and immune responses in goat kids. Small Ruminant Research 69, 115-123.

Spears JW (1996) Organic trace minerals in ruminant nutrition. Animal Feed Science and Technology 58, $151-163$.

Starry JE (1981) The effect of dietary fat on milk composition. In: Haresing, W. (Ed). Recent advances in Animal. Nut. P3. Butterworths. Woburn. MA.

Strnadová P, Svobodová V, Pavlata L, Mišurová L \& Dvořák R (2011) Effect of inorganic and organic zinc supplementation on coccidial infections in goat kids. Acta Veterinaria Brno 80, 131-137.

Thrall MA, Baker C, Campbell TW, DeNicola D, Martin JF, Lassen ED \& Weiser G (2004) Veterinary hematology and clinical chemistry. Philadelphia: Lippincott Williams and Wilkins.

Turner RJ \& Finch JM (1990) Immunological malfunctions associated with low selenium - vitamin E diets in lambs. Journal of Comparative Pathology 126, 2200-2204.

Ward JD \& Spears JW (1997) Long-term effects of consumption of low-copper diets with or without supplemental molybdenum on copper status, performance, and carcass characteristics of cattle. Journal of Animal Science75, 3057-3065.

Wiking L, Larsen T \& Sehested J (2008) Transfer of dietary Zn and fat to milk evaluation of milk fat quality, milk fat precursors, and mastitis indicator. Journal of Dairy Science 91, 1544-1551.

Wittenberg KM \& Boila RJ (1988) Supplementary copper for growing cattle consuming diets high in molybdenum or molybdenum plus sulfur. Canadian Journal of Animal Science68, 1143-1154.

Yoshikawa T \& Naito Y (2002) What Is Oxidative Stress? Journal of the Japan Medical Association124, 1549-1553.

Zhang W, Zhang Y, Zhang S, Xian Z, Jia, Z \& Wang R (2012) Effect of Different Levels of Copper and Molybdenum Supplements on Serum Lipid Profiles and Antioxidant Status in Cashmere Goats. Biological Trace Element Research 148, 309-315. 